\title{
LEARNING WRITING IN PRIMARY SCHOOL (Qualitative Study-Ethnography in SD Islam - Jerapah Kecil Jakarta Timur)
}

\author{
Gusti Yarmi \\ Universitas Negeri Jakarta \\ Jalan Rawamangun Muka No. 1 Jakarta Timur \\ gustiyarmi@ymail.com.
}

\begin{abstract}
The aims of this study is to determine the understanding of the application of learning to writing in Islamic Primary School Jerapah Kecil. This study is a qualitative study using ethnographic methods by Spredly models. This study was conducted in March-July 2013. The results of this study indicate that the teaching of writing in Islamic Primary School jerapah kecil has a unique associated with writing learning objectives, which expects students have writing skills through the practice of writing contextually and directing the students how student happy and loved to writing. Through writing activities teachers can instill a positive attitude to the students. In this study it was found that the approach used in the teaching of writing in addition to using the communicative approach and whole language is also very good on student-centered learning. Writing skills of students trained through various activities at the school. Writing activities performed in the morning activities, the process of learning activities and activities by school program. Writing a journal is a routine activity conducted in the morning activities in order to train skilled student and enjoys writing. Various program activities outside of school in order to stimulate various aspects of development and potential students, including writing. Assessment that teachers do, not just results-oriented, but also the process. Then the aspects that not only the cognitive aspects but also aspects of the attitude or character cultivation. Utilizing a variety of learning resources one museum as a learning resource writing to develop positive attitudes in students through writing activities.
\end{abstract}

Keywords: Learning to write, writing journals, museum

\begin{abstract}
ABSTRAK
Penelitian ini bertujuan untuk mengetahui pemahaman mengenai penerapan pembelajaran menulis di Sekolah Dasar Islam Jerapah Kecil. Penelitian ini adalah penelitian kualitatif dengan menggunakan metode etnografi model Spredly. Penelitian ini dilaksanakan pada bulan Maret-Juli 2013. Hasil penelitian ini menunjukkan bahwa pembelajaran menulis di Sekolah Dasar Islam Jerapah Kecil memiliki keunikan yang berkaitan dengan tujuan pembelajaran menulis, yaitu mengharapkan siswa memiliki keterampilan menulis melalui praktek menulis secara kontekstual dan lebih mengarahkan pada siswa bagaimana siswa senang dan gemar menulis. Melalui kegiatan menulis guru dapat menanamkan sikap positif pada diri siswa. Dalam penelitian ini ditemukan bahwa pendekatan yang digunakan dalam pembelajaran menulis selain menggunakan pendekatan komunikatif dan whole language juga sangat ditekankan pada pembelajaran yang berpusat pada siswa. Keterampilan menulis siswa dilatih melalui berbagai kegiatan yang ada di sekolah. Kegiatan menulis dilakukan pada kegiatan pagi, pada proses kegiatan pembelajaran dan kegiatan program sekolah. Menulis jurnal merupakan kegiatan rutin yang dilakukan pada kegiatan pagi dalam rangka melatih siswa terampil dan gemar menulis. Memprogramkan berbagai kegiatan di luar sekolah dalam rangka menstimulasi berbagai aspek perkembangan dan potensi siswa termasuk menulis. Penilain yang dilakukan guru tidak hanya berorientasi pada hasil tetapi juga proses. Kemudian aspek yang dinilai tidak hanya aspek kognitif namun juga aspek sikap atau penanaman karakter. Memanfaatkan sumber belajar yang bervariasi salah satunya museum sebagai sumber belajar menulis yang dapat mengembangkan sikap positif pada siswa melalui kegiatan menulis.
\end{abstract}

Kata Kunci: Pembelajaran menulis, menulis jurnal, museum 


\section{PENDAHULUAN}

Di era globalisasi ini tulismenulis merupakan salah satu media yang sangat potensial untuk mentransformasikan ide dan pikiran dalam cakupan yang sangat luas. Hal ini dinyatakan oleh Saddhono dan Slamet. (2014: 201). Melalui jasa internet misalnya informasi apapun bisa diakses setiap orang di belahan dunia manapun. Melalui media massa cetak, opini siapa saja dengan mudah bisa mempengaruhi pembaca yang jauh dari jangkauan kemajuan teknologi informasi sekali pun. Agar informasi yang disampaikan dapat dipahami pembaca dengan tepat, diperlukan kemampuan menulis yang memadai. Pendapat ini diperkuat lagi oleh Leonhardt (2001:27) yang menyatakan bahwa saat ini keberhasilan pada hampir semua bidang pekerjaan ditentukan salah satunya oleh kemampuan menulis.

Mengingat peran strategi kegiatan menulis seperti dinyatakan di atas, pihak sekolah harus mengakomodasi dalam proses pembelajaran yang dapat meningkatkan keterampilan menulis. Agar kompetensi menulis tercapai, pembelajaran menulis harus dirancang dengan baik dan menggunakan pendekatan yang tepat. Pembelajaran bahasa diharapkan tidak hanya sekedar menghafal kaidah-kaidah bahasa, tetapi membekali siswa dengan kemampuan berkomunikasi yang bermakna dan kontekstual. Untuk itu kegiatan berbahasa yang dilatihkan kepada siswa, utamanya siswa SD adalah kegiatan berbahasa yang real atau nyata dan bukan artifisial. Pembelajaran yang dilaksanakan harus melibatkan siswa secara aktif. Pembelajaran menulis idealnya tidak diajarkan dengan hanya menekankan pada teori dan hafalan tetapi harus bersifat praktek secara kontekstual.

Ditemukan fenomena di Sekolah Dasar Islam Jerapah Kecil ,sekolah yang diistilahkan oleh kepala sekolah dan guru-gurunya dengan sekolah "laskar pelangi jilid 2," ini sangat fokus untuk mengembangkan berbagai potensi yang ada dalam diri siswanya termasuk menulis melalui berbagai kegiatan yang melibatkan siswa secara aktif. Selain itu sekolah ini juga sangat menekankan pada penanaman sikap siswanya. Pengembangan kemampuan menulis yang dilakukan secara kontekstual tidak hanya melalui proses pembelajaran tetapi juga melalui kegiatan pagi dan melalui berbagai kegiatan sekolah lainnya yang selalu dipadukan dengan kegiatan menulis.

Untuk mengembangkan keterampilan menulis dan menjadikan menulis sebagai sebuah kegemaran diperlukan kondisi yang mendukung. Kondisi belajar seperti yang dikemukakan Cambourne merupakan pengembangan penelitian linguistik, yaitu studi pemerolehan bahasa. Bila guru dapat memahami dan mengaplikasikan teori itu, siswa akan memiliki perubahan dalam keterampilan dan strategi pengembangan keaksaraan.

Cambourne (1995:184-187) menjelaskan bahwa istilah kondisi adalah keadaan tertentu (melakukan, berperilaku,menciptakan), yang merupakan kesatuan utuh dan bersinergi, yang memengaruhi dan dipengaruhi antara yang satu dan yang lain. Kondisi-kondisi tersebut adalah (1) penenggelaman (immersion), (2) pemodelan (demonstration), (3) ke- 
terlibatan (engagement), (4) harapan (expectation), (5) tanggung jawab (responsibility), (6) penggunaan/ pengkaryaan (employment) (7) penghampiran (approximation), dan (8) tanggapan (response). Kedelapan kondisi tersebut diuraikan sebagai berikut.

Penenggelaman mengacu pada keadaan yang dipenuhi, diselimuti, dibanjiri, didalami, atau terus-menerus di dalam objek yang dipelajari. Pemodelan mengacu pada kemampuan untuk mengamati tindakan, sehingga semua pembelajaran dimulai dengan demonstrasi dari beberapa tindakan. Selain dari penenggelaman dan pemodelan kondisi yang diperlukan untuk terjadinya pembelajaran adalah melibatkan potensi siswa melalui demonstrasi dan berada di tempat penenggelaman. Harapan merupakan pesan esensial yang signifikan ketika berkomunikasi dengan siswa. Para siswa didorong untuk dapat membuat keputusan (bertanggung jawab). Para siswa harus diberi akses untuk menampilkan kemampuan beraksara, sehingga penghampiran perlu dilakukan, yang berarti guru harus memberikan akses secara luas. Penggunaan mengacu pada peluang untuk mengaplikasikan dan melakukan praktik dari yang telah dipelajari. Tanggapan merupakan umpan balik atau informasi yang diterima pemelajar, dan biasanya diberikan orang lain yang berpengaruh dalam kehidupan pemelajar.

Cere menyatakan menulis merupakan salah bentuk komunikasi. Selanjutnya dikatakan bahwa di dalam komunikasi terdapat empat unsur, yaitu: (1) menulis merupakan bentuk ekspresi diri; (2) menulis merupakan sesuatu yang umum di- sampaikan ke pembaca; (3) menulis merupakan aturan dan tingkah laku; dan (4) menulis merupakan sebuah cara belajar. Sebagai bentuk dari ekspresi diri, menulis bertujuan untuk mengkomunikasikan, menyampaikan sebuah ide melewati batas waktu dan ruang. Artinya, menulis dapat dilakukan kapan saja, dan di mana saja sesuai dengan keadaan yang terdapat dalam diri penulis.

Penelitian yang telah dilakukan oleh Joko pada tahun 2014 tentang pengembangan budaya keaksaraan di SMAN 78 Jakarta yang telah memberikan peta baru tentang keaksaraan pada jenjang pendidikan formal

Hal ini dimaksudkan pemilihan aktivitas pendidikan di sekolah dasar dalam penelitian ini merupakan latar yang menarik karena akan membedakan dengan peneltian yang dilakukan sebelumnya. Penelitian pembelajaran menulis di SD Islam Jerapah Kecil Jakarta Timur dapat memberikan peta baru tentang keaksaraan dalam hal ini lebih spesifik pada pengembangan ke-mampuan menulis pada jenjang pendidikan tingkat sekolah dasar.

Berdasarkan latar belakang dan uraian teoretik tersebut, kajian etnografi sangat tepat dilakukan untuk menjelaskan pengembangan kemampuan atau budaya menulis. Spradley (1997:3) menjelaskan bahwa etnografi merupakan pekerjaan mendeskripsikan suatu kebudayaan, sedangkan Emzir (2010: 152-153) mengatakan bahwa istilah etnografi mengacu pada penelitian sosial yang memiliki beberapa karakteristik sebagai berikut, perilaku manusia dikaji dalam konteks sehari-hari, data dikumpulkan dari suatu rentangan sumber, pendekatan untuk pengumpulan data 
tidak terstruktur, fokus penelitian biasanya merupakan suatu latar tunggal atau kelompok dari skala yang relatif kecil, dan analisis data melibatkan interpretasi arti dan fungsi tindakan manusia.

Oleh karena itu, kajian ini bertujuan untuk memperoleh pemahaman yang mendalam tentang pembelajaran menulis di SD Islam Jerapah Kecil Jakarta Timur. Tujuan tersebut dirinci sebagai berikut (1) Tujuan pembelajaran menulis (2) Kegiatan dalam pembelajaran menulis.

\section{Metodologi Penelitian}

Penelitian ini dilakukan di Sekolah Dasar Islam Jerapah Kecil Jakarta Timur. Penelitian dilaksanakan pada bulan Maret 2012 sampai dengan Juli 2013.

Pendekatan yang digunakan adalah pendekatan kualitatif dalam bentuk etnografi. Teknik pengumpulan data yang digunakan adalah pengamatan, wawancara, dan analisis dokumen. Data yang terkumpul dianalisis dengan teknik analisis kualitatif model Spradley, meliputi analisis domain, analisis taksonomi, analisis komponen, dan tema.

Prosedur pengumpulan data dilakukan melalui pengamatan berperan serta, wawancara, dokumen dan rekaman. Dalam pengamatan berperan serta, peneliti mengandalkan diri sendiri sebagai alat pengumpul data dan terlibat secara penuh. Wawancara dilakukan untuk mengumpulkan data yang lebih dalam, setelah pengamatan berperan serta berlangsung. Peneliti juga mengumpulkan data, di samping dari sumber tertulis, seperti dokumen- dokumen, juga dari sumber tak tertulis, seperti foto atau video. Lebih lanjut, peneliti membuat catatan lapangan dan rekaman dengan tape recorder atau media lain sebagai perekam.

Prosedur analisis data dilakukan melalui empat tahap analisis, yaitu domain, taksonomi, komponensial, dan tema budaya. Analisis domain dilakukan untuk memperoleh gambaran umum dan menyeluruh dari objek penelitian atau situasi sosial. Analisis taksonomi dilakukan untuk menjabarkan domain yang dipilih menjadi lebih rinci sehingga struktur internal diketahui. Analisis komponensial dilakukan untuk mencari-ciri spesifik pada setiap struktur internal dengan mengkontraskan antar elemen. Analisis tema budaya dilakukan untuk mencari hubungan di antara domain dan hubungan keseluruhan, yang selanjutnya dinyatakan ke dalam tema-tema yang sesuai dengan fokus dan subfokus penelitian.

Pengujian keabsahan data dilakukan dengan kepercayaan, keteralihan, kebergantungan, dan kepastian. Kredibilitas data yang digunakan berupa perpanjangan keikut sertaan, ketekunan pengamatan, dan triangulasi. Keteralihan data dilakukan dengan deskripsi rinci, sehingga hasil penelitian dapat ditransfer selama kondisi sama persis. Kebergantungan dan kepastian data dilakukan dengan teknik auditing, yaitu melakukan konsultasi secara intensif dengan ahli untuk melihat kriteria kepastian dan kebergantungan data tersebut. 


\section{Hasil Penelitian dan Pembahasan}

\section{Tujuan Pembelajaran Menulis}

Tujuan yang ingin dicapai dalam pembelajaran menulis di SD Islam Jerapah Kecil ada tiga sasaran yang ingin dicapai. Pertama, siswa memiliki keterampilan menulis. Kedua, siswa gemar atau senang menulis. Ketiga, mengembangkan sikap positif siswa melalui menulis. Adapun terkait dengan kompetensi yang dikembangkan agar siswa memiliki keterampilan menulis mengacu pada SK dan KD yang ada dalam kurikulum 2006. Secara umum tujuan pembelajaran menulis di kelas IV dan $\mathrm{V}$ ini terdiri atas dua aspek yaitu siswa mampu menulis berbagai bentuk karangan dan menguasai kaidah-kaidah penulisan.

Tujuan pembelajaran menulis ini dicapai melalui aktivitas atau kegiatan yang dilakukan oleh siswa selama proses pembelajaran. Berikut ini adalah tujuan pembelajaran bahasa Indonesia dengan fokus menulis yang dikembangkan di kelas IV dan $\mathrm{V}$ SD. Tujuannya adalah dengan diberikan contoh siswa mampu menulis cerita tentang pengalaman yang berkesan dengan menggunakan ejaan dan tanda baca yang benar. Pencapaian tujuan keterampilan menulis ini dicapai melalui kegiatan menulis sebagai sebuah proses. Hal ini dapat digambar pada beberapa data berikut. Kegiatan pembelajaran dimulai dengan siswa menyimak guru bercerita tentang pengalaman guru yang berkesan di saat liburan. Berdasarkan contoh dari guru tersebut siswa diminta untuk mengingat pengalaman mereka di saat liburan. Siswa diminta duduk berkelompok kemudian setiap siswa me- nuliskan topik tentang pengalaman mereka yang berkesan di saat liburan dan mengemukan dalam kelompoknya. Setelah itu siswa secara individual diminta memilih satu topik dan menuliskannya dalam bentuk cerita secara tertulis. Siswa setelah itu diminta duduk berkeliling membetuk lingkaran. Kemudian siswa secara bergiliran diminta untuk membacakan cerita yang sudah ditulis. Siswa yang lain menyimak dan setelah selesai temannya membacakan ceritanya, siswa diminta bertanya tetang cerita temannya tersebut.

Dari proses pembelajaran yang dilakukan di SD Islam Jerapah Kecil dapat diketahui bahwa tujuan pembelajaran menulis termasuk menulis puisi akan mudah dilakukan oleh siswa apabila siswa diminta menuliskan hal-hal yang betul-betul dialaminya. Artinya siswa tidak diminta mengungkapkan sesuatu yang artifisial. Karena kalau artifisial siswa akan mengalami kesulitan dan mengungkapkan ide, gagasan, dan perasaannya. Hal ini sejalan dengan pendapat Goodman yang menyatakan bahwa bahasa yang mudah dipelajari apabila pembelajaran bahasa tersebut nyata, alamiah, masuk akal, menarik, relevan dengan kehidupan anak, milik anak, merupakan bagian peristiwa nyata, memiliki fungsi sosial, memberi makna, penggunaannya sesuai dengan pilihan anak, dapat dikuasai anak, anak memiliki kemampuan menggunakannya.

Sebaliknya bahasa akan sulit dipelajari apabila artifisial artinya tidak sesuai dengan penggunaan sesungguhnya, terpotong-potong artinya tidak holistik, tidak masuk 
akal, membosankan, tidak relevan, milik orang lain, berada di luar konteks, tidak memiliki fungsi sosial, tidak memberi makna, penggunaan dipaksakan, tidak dapat dikuasai, anak tidak memiliki kemampuan menggunakannya.

Tujuan pembelajaran menulis di SD Islam Jerapah Kecil berikutnya adalah siswa dilatih untuk mengembangkan berbagai hal berkaitan dengan sikap atau juga proses mental siswa. Seperti kemampuan berpikir kritis, percaya diri, bekerja sama. Kemampuan berpikir kritis misalnya dikembangkan dengan melatih siswa untuk mengajukan pertanyaan kepada guru atau juga kepada nara sumber lainnya. Penanaman sikap positif ini dikembangkan melalui kegiatan menulis jurnal yang dilakukan sebagai kegiatan pagi. Setiap pagi sebelum pembelajaran dimulai setiap siswa mengikuti kegiatan menulis jurnal. Melalui kegiatan menulis jurnal ini siswa diminta membuat bermacam-maca bentuk tulisan yang bersifat ekspresif. Seperti, menulis petunjuk, menulis kesan terhadap sesuatu. Melalui kegiatan menulis jurnal siswa dapat mengembangkan berbagai potensi siswa selain kompetensi menulis. Hal ini sejalan dengan pendapat yang dikemukakan oleh Routman (1991:199-200) bahwa menulis jurnal dapat melatih siswa terampil menulis, membaca, berani mengambil dan menghadapi resiko, mevalidasi pengalaman dan perasaan pribadi , mengembangkan kemampuan berpikir, memberi kesempatan merefleksi diri. Hal ini juga sejalan dengan tuntutan kurikulum terbaru yang digunakan di Indonesia, yaitu kurikulum 2013. Siswa dilatih untuk mengamati, menanya bernalar, me- ngujicobakan, dan mengkomunikasikan. Selain itu, melalui pembelajaran bahasa Indonesia dengan fokus menulis siswa juga dilatih kepercayaan dirinya, misalnya ketika siswa dilatih untuk membacakan hasil karyanya di hadapan teman-temannya.

\section{Kegiatan Pembelajaran Menulis}

Kegiatan menulis yang dilakukan siswa dalam pembelajaran bahasa Indonesia adalah kegiatan menulis yang sesungguhnya sesuai dengan konteks dan yang betul-betul berguna dalam kehidupan. Berdasarkan hasil pengamatan diketahui kegiatan menulis di SD Islam Jerapah Kecil dilakukan dalam tiga proses. Pertama pada kegiatan pagi. Pada kegiatan pagi siswa dilatih menulis melalui menulis jurnal harian. Melalui pengembangan berbagai tema. Siswa dilatih untuk mengungkapkan ide, gagasan, pendapat, dan perasaan mereka secara tertulis. Adapun kegiatan-kegiatan yang dilatihkan, misalnya siswa dilatih atau diminta menuliskan pengalaman yang berkesan, menulis laporan, menulis puisi, menuliskan perbuatan baik yang pernah dilakukan siswa kepada orang lain, menulis laporan hasil wawancara, menulis kartu ucapan, menulis kartu undangan, mengungkapkan perasaan, megungkapkan sikap baik yang dimiliki siswa, menulis petunjuk, menulis cerita, menuliskan hal yang menyenangkan di sekolah.

Menulis jurnal ini sangat beranfaat untuk mengembangkan berbagai potensi siswa. Selain mengembangkan kemampuan menulis juga dapat mengembangkan sikap positif. Adanya kegiatan menulis 
jurnal ini sejalan dengan penciptaan kondisi yang mendukung pengembangan kemampuan berbahasa seperti dikemukakan oleh Cambourne (1995: 184-187) Kondisi-kondisi tersebut adalah (1) penenggelaman (immersion), (2) pemodelan (demonstration), (3) keterlibatan (engagement), (4) harapan (expectation), (5) tanggung jawab (responsibility), (6) penggunaan/pengkaryaan (employment) (7) penghampiran (approximation), dan (8) tanggapan (response).

Selain itu, dengan berbagai bentuk tulisan dalam kegiatan menulis jurnal yang dihasilkan siswa secara teori dapat dikatakan ada beberapa jurnal. Menurut Cox (1999) ada beberapa jenis jurnal, yaitu jurnal personal, jurnal komunitas, jurnal ide, jurnal, literacy, jurnal dialog. Hal ini juga sesuai dengan pendapat Pappas yang menyatakan ada beberapa jenis jurnal yaitu jurnal pribadi, jurnal catatan pembelajaran, dan jurnal dialog. (1990:289)

Selanjutnya kegiatan menulis yang pokok dan dominan dilakukan pada saat pembelajaran inti. Kegiatan menulis yang dikembangkan dalam pembelajaran inti mengacu pada kompetensi dasar yang sudah tercantum dalam kurikulum. Kegiatan yang dilakukan, misalnya menulis cerita yang berkesan, menulis cerita hasil pengamatan, menulis cerita hasil wawancara, menulis puisi, menulis surat. Kegiatan inti pelaksanaan kegiatan menulis lebih berorientasi pada praktek menulis, bukan pada teori menulis. Siswa diberi pengalaman menulis yang sebenarnya secara kontekstual. Apa yang akan dituliskan oleh siswa sesuai dengan apa yang dialami dan diketahui siswa. Intinya pembelajaran menulis lebih menekankan pada proses menulis bukan pada produk menulis. Siswa yang melakukan kesalahan dalam menulis adalah dianggap guru sebagai sesuatu yang wajar.

Pembelajaran menulis sebagai proses, siswa melakukan kesalahan dalam menulis adalah hal yang manusia dan wajar. Guru harus memperhatikan jenis-jenis kesalahan yang dibuat murid dan tidak selalu melihatnya sebagai sesuatu yang negatif. Yang terpenting adalah pengakuan bahwa murid menjadi dewasa dan mencoba hal baru, bentuk yang lebih canggih, mereka mungkin untuk sementara membuat kesalahan lebih banyak saat mereka mengembangkan wawasan

Selain kegiatan pagi dan kegiatan inti pembelajaran kegiatan menulis juga dilakukan setiap aktivitas atau program yang dikembangkan di sekolah. Hampir semua kegiatan yang dilaksanakan sekolah memasukkan aktivitas menulis di dalamnya.

Keterampilan berbahasa secara produktif yang dipergunakan secara tidak langsung, tidak secara tatap muka dengan orang lain. Maka dalam proses pembelajaran dituntut pula kesempatan bagi siswa untuk berlatih menulis. Dalam kegiatan itu siswa harus terampil memanfaatkan unusur grafologi, struktur bahasa atau kosa kata. Keterampilan dalam memanfaatkan unsur-unsur tersebut tidak akan datang secara otomatis, melainkan harus melalui latihan dan praktik secara teratur Beberapa kegiatan yang dapat dirancang dan digunakan dalam pembelajaran menulis di kelas yaitu : 1). Bermain-main dengan bahasa dan tulisan, 2). Kuis , 
3). Memberi atau mengganti akhir cerita, 4). Menulis meniru model, 5). Strategi menulis buku harian, 6). Menyelenggarakan majalah dinding (Mading), 7). Menulis abjad. 8) Menulis Kegiatan 9). Menulis Diary/ Buku Harian 10). Menulis Mainan Kesenangan 11). Menulisi Gambar Kesayangan 12). Menulis Bentuk Gambar 13). Menulis Cerita Berbantuk Akordion 14). Menulis Cara Memainkan sesuatu , 15) Menulis Poster/Reklame 16). Menulisi Ben da-Benda Pos.

Dari uraian di atas dipahami bahwa kegiatan menulis yang dilakukan di SD Islam Jerapah Kecil bermakna bagi siswa. Karena kegiatan menulis dilakukan dalam konteks yang sesuungguhnya. Kegiatan menulis tidak hanya diilakukan pada pembelajaran inti, namun juga dilakukan pada kegiatan pagi maupun pada setiap kegiatan yang diselenggarakan sekolah. Namun untuk menyempurnakan kegiatan menulis tersebut perlu disempurnakan dalam hal perencanaan maupun dalam proses kegiatan menulis. Kegiatan menulis diupayakan lebih mengembangkan potensi siswa.

Penelitian ini memiliki keterbatasan dari segi cakupan maslah yang diteliti. Pembelajaran Bahasa Indonesia di SD meliputi empata keterampilan berbahasa, yaitu membaca, menulis, menyimak, dan berbicara. Namun dalam penelitian ini karena keterbatasan waktu penelitian, penelitian hanya difokuskan pada pembelajaran keterampilan menulis.

\section{Simpulan dan Rekomendasi}

Berdasarkan uraian di atas
dapat disimpulkan bahwa pelak- sanaan pembelajaran menulis di SD Islam Jerapah Kecil secara umum dilaksanakan dengan menarik dan dengan pembelajaran yang melibatkan siswa secara aktif. Secara khusus dapat disimpulkan: (1) Tujuan yang ingin dicapai dalam pembelajaran menulis memiliki tiga sasaran, yaitu a. Siswa memiliki keterampilan menulis. b. Siswa memiliki kegemaran menulis, c. Mengembangkan sikap positif siswa. Dalam merumuskan tujuan pembelajaran menulis guru memperhatikan bahwa yang menjadi sasaran tujuan bukan kepada pemberian pengetahuan tentang kaidah menulis tetapi lebih difokuskan pada bagaimana siswa mampu menulis melalui praktek menulis yang sesungguhnya secara kontekstual. (2) Kegiatan menulis yang dilakukan siswa dalam pembelajaran bahasa Indonesia adalah kegiatan menulis yang sesungguhnya sesuai dengan konteks dan yang betul-betul berguna dalam kehidupan. Kegaiatan menulis tidak hanya dilakukan dalam pembelajaran Bahasa Indonesia, tetapi juga pada kegiatan pagi, kegiatan di luar sekolah. Temuan Khusus dalam penelitian ini (1) Menekankan pada Praktek Menulis bukan pada Teori Menulis melalui (a) Menulis Jurnal, (b) Menulis Berita Pagi, (c) Menulis Laporan Hasil Pengamatan dan Kunjungan, (d) Menulis Petunjuk (2) Melibatkan Orang Tua dalam Pembelajaran termasuk Menulis, (3) Menjadikan Museum sebagai Sumber Belajar Menulis. (4) Mengembangkan Kemampuan Menulis melalui Berbagai Program Sekolah.

Rekomendasi penelitian ini ditujukan baik kepada guru dan/atau 
sekolah maupun kepada peneliti lanjut. Peneliti lanjut diharapkan untuk melakukan penelitian lanjutan karena keterbatasan penelitian ini, sehingga pembelajaran menulis dapat dilakukan dengan lebih baik, terutama di sekolah dasar. Guru diharapkan untuk memahami dan mengaplikasikan hasil kajian ini ke dalam pembelajaran menulis, sehingga siswa akan lebih berhasil studi di sekolah, khususnya sekolah dasar.

\section{DAFTAR PUSTAKA}

Akhadiah dkk. Pembinaan

Kemampuan Menulis Bahasa Indonesia. Jakarta: Grasindo, 1992

Benny A. Pribadi, Model Desain Sistem Pembelajaran. Jakarta: Dian Rakyat, 2010

Cere, Anne Roggles. Writing and Learning. New York: McMillan Publishing Company, 1995

Cambourne, Brian, "Toward an Educationally Relevan Theory of Literacy Learning: Twenty Years of Inquiry", The Reading Teacher, Vol. 49 , No. 3, November 1995, pp. 182190

Christine C. Pappas, Barbara Z. Kiefer, Linda. Levstik. An Integrated Language Perspective in the Elementary School. Longman: Library of Congres, 1990

Cox Carole. Teaching Language Arts.California State University. 1999.

Donna E. Norton, The Effetive Teaching of Language Arts,
(Columbus, Ohio: Charles E. Merrill Publishing Co, 1980

Ken Goodman, What's Whole in Language in The 21 st Century?.New York: Garn Press, 2014

Leonhardt, 99 Cara Nenjadikan Anak Anda Bergairah Menulis, (Bandung: Kaifa, 2001

Rofi'udin dan Zuhdi. Pendidikan Bahasa dan Sastra Indonesia di Kelas Tinggi, Jakarta: Proyek PGSD, 1999

Robert M. Gagne, Leslie J. Briggs, dan Walter W. Wager, Principles of Instructional Design .New York: Harcout, 1992

Routman, Invitations Changing as Teacher and Learner, (Portsmouth NH: Heinemann, 1991

Saddhono dan Slamet, Pembelajaran Keterampilan Berbahasa Indonesia, Yogyakarta: Graha Ilmu, 2014 